\title{
STUDY OF 7 BUILDING DEVELOPMENT PLANNING SPECIFICATION OF STEEL FRAMEWORK STRUCTURE (BASED ON SNI 1729 - 2015) (CASE STUDY: OFFICE BUILDING CONSTRUCTION PROJECT)
}

\author{
Tomi Admanegara \\ Faculty of Engineering, Narotama University Surabaya \\ tomyadma4@gmail.com \\ Koespiadi \\ Faculty of Engineering, Narotama University Surabaya
}

\begin{abstract}
Steel is a material that is widely used in industrial development and buildings with functions as the main building frame. This plan aims to plan a building structure with 7 floors plus a ground floor that will function as an office building with analysis using a Structure Analysis Program (SAP 2000 v.19) combined with steel regulations on SNI 1729: 2015. Based on the results of SAP analysis 2000 v.19 produces a column structure using WF Steel $400 \times 400 \times 30 \times 50$ with the beam 1 using the profile of Steel WF $350 \times 300 \times 14 \times 23$ and for the

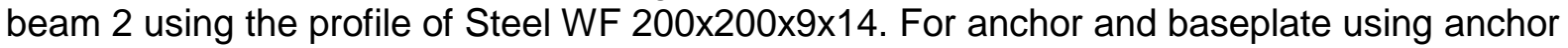
M-25 with a length of $400 \mathrm{~mm}$, with baseplate thickness of $25 \mathrm{~mm}$ and for bolts using M-25 bolts with a total of 16 bolts.
\end{abstract}

Keywords: Building Planning, Steel Frame Building, SAP 2000 v.19.

\section{INTRODUCTION}

Steel is a structure that is often used in multi-story buildings. Structural planning can be defined as a mixture of art and science combined with an expert structure institution regarding structural behavior with the basis of knowledge in statics, dynamics, material mechanics and structural analysis.

This plan uses the SNI 1729: 2015 regulations which are used in the calculation of current steel structures. In this plan using SAP 2000 v.19 modeling analysis combined with SNI 1729: 2015 regulations. This plan is used to analyze the capacity of the column structure, structure, and analysis on connection and anchor referring to the regulations concerning the applicable SNI.

This study aims to analyze the construction of office buildings using a steel frame structure that uses SNI 1729: 2015, to determine the strength of column and beam structures and to determine the needs of column and beam structures. The location of this study is at Bukit Golf Citraland, Surabaya City.

\section{Review of Research Previously}

The steel structure is the type of steel based on economic considerations, its strength, suitable for load bearers (PADOSBAJOYO, 1994). Steel structures are widely used for multistory columns and beams, roof support systems, hangars, bridges, antenna towers, and others. During the period of introduction of steel as a building material until 1960, the steel used was carbon steel as the ASTM (American Society for Testing and Materials). Currently, there are many steel profiles that allow planners to increase the strength of the material in 
the area of stress, so there is no need to increase the size of the stem dimension. Planners can decide based on the maximum rigidity or the lightest weight.

Structural planning according to Steel Building Building Specifications (SNI 1729: 2015) has a goal of producing a structure that is stable, strong, durable, and fulfills other objectives such as the economy and ease of implementation. A building is said to be stable if it is not easily rolled, tilted, or displaced during the age of the building plan. The risk of structural failure and loss of ability over the life of the plan can be minimized within acceptable limits. According to the journal from Budiman and HeriKhoeri with the title "Comparative Study of Steel Structures using WF Profile on HSS Profiles in Structure Columns" with conclusions where construction of construction is closely related to a structure that supports the construction. And the results of the study show that profiles using the HSS (Hollow Structural Section) profile column have a greater deviation, a greater stress ratio and a lighter weight of steel construction compared to the WF (Wide Flange) profile.

\section{Basic Theory Used Imposition}

Loading and combination of structural planning in building construction must take into account loadings such as dead loads, live loads, earthquake loads, wind loads, rain loads, and a structure must meet the strength of the plan by using a combination of SNI 1727: 2013 as follows:
1) $1.4 \mathrm{D}$
2) $1.2 \mathrm{D}+1.6 \mathrm{~L}+0.5(\mathrm{La}$ or $\mathrm{H})$
3) $1.2 \mathrm{D}+1.6(\mathrm{La}$ or $\mathrm{H})+(\mathrm{YL}$. L or $0.8 \mathrm{~W})$
4) $1.2 \mathrm{D}+1.3 \mathrm{~W}+\mathrm{YL} . \mathrm{L}+0.5(\mathrm{La}$ or $\mathrm{H})$
5) $1.2 \mathrm{D} \pm 1.0 \mathrm{E}+\gamma \mathrm{L}$. $\mathrm{L}$
6) $0.9 \mathrm{D}+(1.3 \mathrm{~W}$ or $1.0 \mathrm{E})$

According to the Earthquake Resilience Planning Procedure for Building Structure and Non-Building (SNI 1726:2012) the effect of the earthquake plan that must be reviewed in the planning and evaluation of building structures and non- building as well as various parts and equipment in general. In determining a class of sites classified according to the properties of the soil on the site, which includes the class sites SA, SB, SC, SE, or SF based on the results of data on the land investigation.

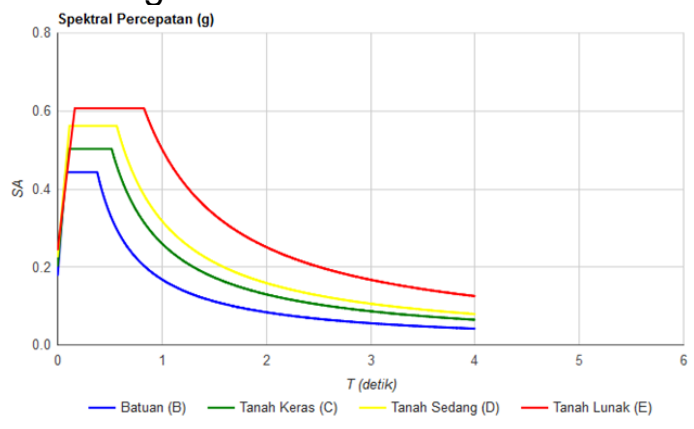

Figure 1.Spectrum Image of Surabaya City Design Response.

\section{Structural Analysis}

1. Beam Design

Loading on the beam is adjusted to the Indonesian Building Regulation (PPIUG)

Regulation 1983, while the use of profiles is calculated based on SNI 1729: 2015.

a. The Examination of the cross section is found in SNI 1729: 2015 :

$$
\frac{b f}{2 x t f} \leq \lambda<0,38 \sqrt{\frac{E s}{f y}}
$$




$$
\frac{d}{t w} \leq \lambda<2,45 \sqrt{\frac{E s}{f y}}
$$

b. Examination Effect of lateral buckling and flexural strength

$$
\begin{aligned}
& \text { Lbmax }=0,086 \times \text { iy } \times \frac{E s}{f y} \\
& L p=1,76 \times \text { iy } \times \sqrt{\frac{E s}{f y}}
\end{aligned}
$$

c. Check the beam shear strength

$$
\text { Shear Ratio }=\frac{V u}{\phi s \times V n}
$$

d. Examination of slime and Shear Interactions

$$
\frac{M u}{\Phi b x M n}+0,625 x \frac{V u}{\Phi s \times V n}<1,375
$$

2. Coloumn Design

a. The Examination of the cross section

For Wings :

For Body :

$$
\frac{b f}{2 x t f} \leq \lambda=0,38 \sqrt{\frac{E s}{f y}}
$$

b. Field check of slider column

$$
\frac{d}{t w} \leq \lambda=2,45 \sqrt{\frac{E s}{f y}}(1-0,93 \times C a)
$$

c. Field axial capacity check

$$
\text { Lbmax }=0,086 \times \text { iy } x \frac{E s}{f y}
$$

- Determining the effective length of the column by using the Direct

Analysis Method (DAM) :

$$
\begin{array}{ll}
\lambda \mathrm{x} & =\frac{k x+L b}{i x} \\
\lambda \mathrm{y} & =\frac{k y+L b}{i y}
\end{array}
$$

- Check the tension of the elastic buckling

$$
\text { Fey }=\frac{\pi^{2} x E s}{\lambda y^{2}}
$$

\section{METHODOLOGY}

This steel portal structure has 7 levels in addition to the presence of a ground floor and rooftop that uses no roof with a height between $4 \mathrm{~m}$ floors and varying distances between columns. The data obtained is then processed and analyzed. The stages of office building planning are like the flow chart in the picture below : 


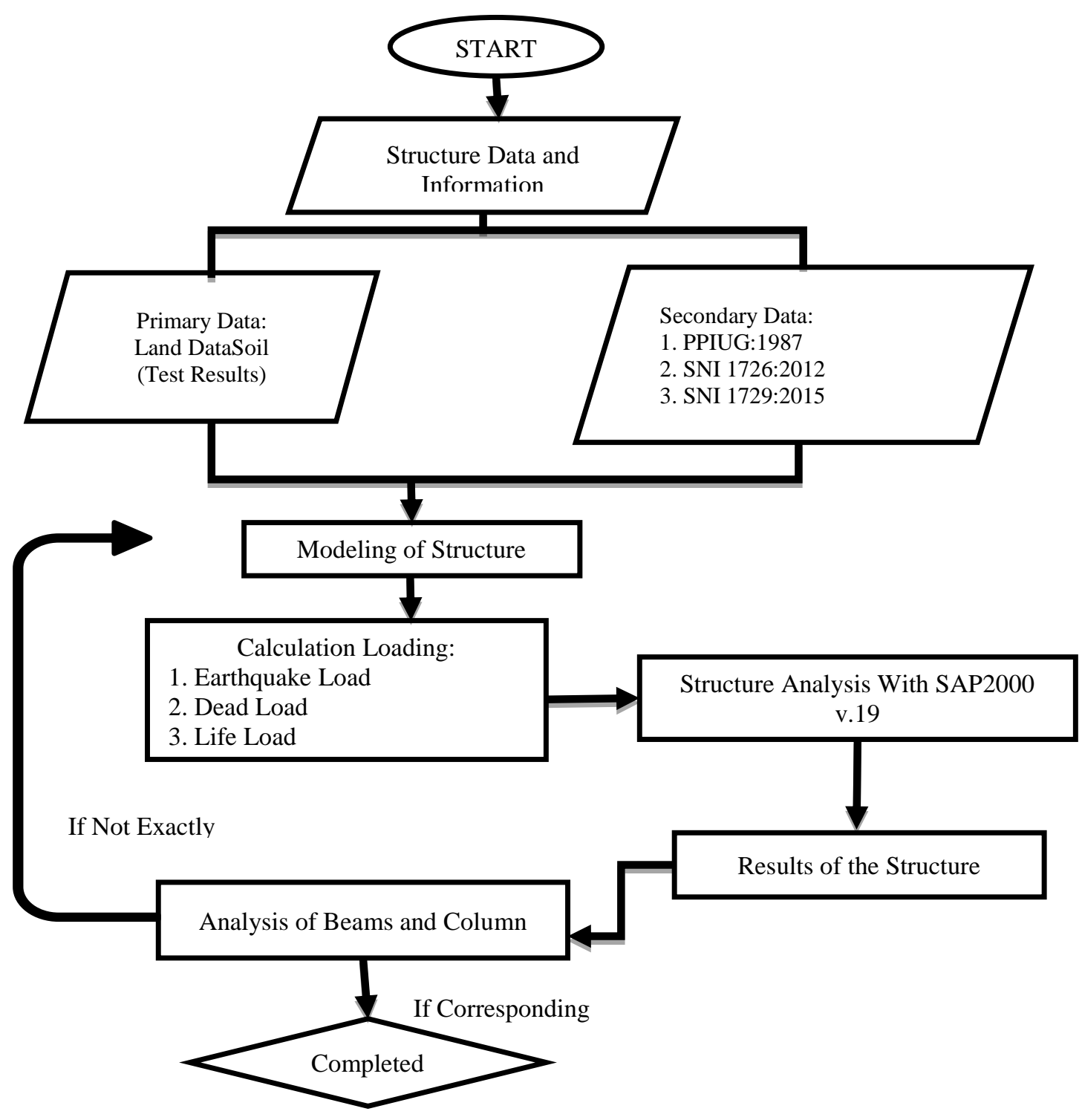

Figure 2. Research Methods

\section{RESULTS AND DISCUSSION}

In planning a 7story office building plus 1 ground floor, the structure is planned and designed using the SAP 2000 v.19 program then an analysis of the working structure is carried out.

\section{Preliminary Design}

Based on preliminary data and planning analysis at the beginning, the steel structure will be used as follows: 
Table 1.Structure Plan Table

\begin{tabular}{ccc}
\hline 1 & Beam 1 & WF $250 \times 175 \times 7 \times$ \\
& & 11 \\
2 & Beam 2 & WF $200 \times 125 \times 6 \times$ \\
& & 9 \\
3 & Column & WF $400 \times 300 \times 10 \times$ \\
& & 16 \\
\hline
\end{tabular}

\section{pectrum Response}

Calculation of seismic load and spectrum response analysis in this office building construction project uses an excel program and is combined with spectra design applications on the website www.puskim.pu.go.id. The results of these data are the classification of soil types of soil rock sites (SB). in determining the spectrum response of the earthquake on the ground we use a seismic period of 0.2 seconds and 1 second, which results in:

$$
\begin{aligned}
& \text { Sms }=0.662 \\
& \text { Sm1 }=0.248 \\
& \text { Sds }=0.44 \\
& \text { Sd1 }=0.164
\end{aligned}
$$

from the above data we get the spectrum response graph image:

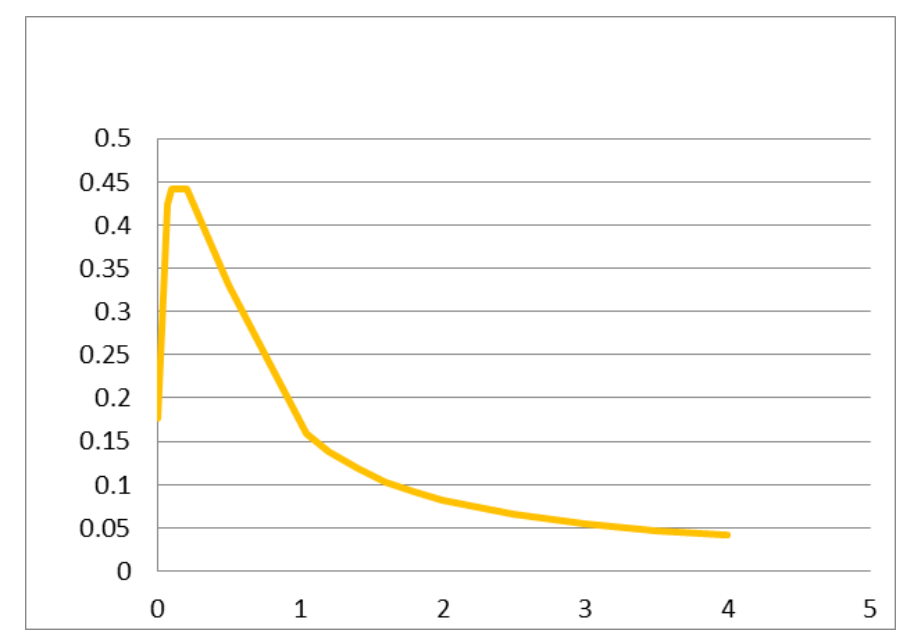

Figure 3. Figure Spectrum Response Graph

With values:

Response Modification Coefficient $(R)=8$,

Strong factor - more system $(\mathrm{Cd})$

Deflection enlargement factor $(\Omega \circ)$

$$
\begin{aligned}
& =3, \\
& =5.5 .
\end{aligned}
$$

\section{SAP Analysis and Structure}

The results of structural analysis using Structure Analysis Program (SAP 2000 v.19) then obtained the profile and calculation of connections as in the table below: 
Table 2. SAP Analysis Results Table :

\begin{tabular}{|c|c|c|c|c|}
\hline No & Profile & Control & Results & Description \\
\hline \multirow[t]{9}{*}{1} & \multirow{9}{*}{$\begin{array}{c}\text { WFBeam } 1 \\
350 \times 300 \times 14 \times \\
23\end{array}$} & 1. Cross & $7.95 \leq 10.96$ & \multirow{4}{*}{$\begin{array}{l}\text { Sectional } \\
\text { Compact }\end{array}$} \\
\hline & & SectionExamination & $25 \leq 70.725$ & \\
\hline & & & $\mathrm{Lb} \leq \mathrm{Lb} \max$ & \\
\hline & & $\begin{array}{l}\text { 2. Inspection of Lateral } \\
\text { and Bending Strong Effect }\end{array}$ & $\begin{array}{c}\text { with } \\
\text { Moment Ratio }\end{array}$ & \\
\hline & & & & \multirow[t]{2}{*}{ Eligible } \\
\hline & & & $0.17<1$ & \\
\hline & & 3. Inspection of Beam & Ratio Shear & Eligible \\
\hline & & & & \multirow[t]{2}{*}{ Eligible } \\
\hline & & $\begin{array}{l}\text { 4. Bending and Shear } \\
\text { Interaction Check }\end{array}$ & $\begin{array}{c}0.232084< \\
1.375\end{array}$ & \\
\hline \multirow[t]{7}{*}{2} & \multirow{7}{*}{$\begin{array}{c}\text { WF Beam } 2 \\
200 \times 200 \times 9 \times \\
14\end{array}$} & 1. Cross & $6.25 \leq 10.96$ & Sectional \\
\hline & & SectionExamination & $\begin{array}{l}20 \leq 70.725 \\
\text { Lb } \leq \text { Lb max }\end{array}$ & Compact \\
\hline & & 2. Inspection of Lateral & Moment & Eligible \\
\hline & & & $0.0125<1$ & \multirow[t]{2}{*}{ Eligible } \\
\hline & & 3. Inspection of Beam & Ratio Shear & \\
\hline & & Sliding & $\begin{array}{c}0.001<1 \\
0.019739<\end{array}$ & \multirow[t]{2}{*}{ Eligible } \\
\hline & & $\begin{array}{l}\text { 4. Bending and Shear } \\
\text { Interaction Check }\end{array}$ & 1.375 & \\
\hline \multirow[t]{8}{*}{3} & \multirow{8}{*}{$\begin{array}{c}\text { ColoumnWF } \\
400 \times 400 \times 30 \times \\
50\end{array}$} & 1. Examination of & Wings: & Sectional \\
\hline & & $\begin{array}{l}\text { Slenderness of Section } \\
\text { Column }\end{array}$ & & Compact \\
\hline & & & $\begin{array}{c}0,0127< \\
0.125\end{array}$ & \multirow{2}{*}{ Eligible } \\
\hline & & & $\begin{array}{c}\text { Maka : } 13.3< \\
70.30\end{array}$ & \\
\hline & & $\begin{array}{l}\text { 2. Examination of } \\
\text { Slenderness of Column }\end{array}$ & $\mathrm{Lb}<\mathrm{Lb} \max$ & Eligible \\
\hline & & Elements & & Eligible \\
\hline & & 3 Canacity Check in Axial & $0.01297<1$ & \\
\hline & & $\begin{array}{l}\text { Column } \\
\text { 4. Sliding Examination } \\
\text { OnColumn }\end{array}$ & $\begin{array}{l}172.8> \\
14.332\end{array}$ & Eligible \\
\hline
\end{tabular}

Angkur, Baseplat, and Connection follows:

Analysis of Angkur and Baseplat which will be used in planning office buildings as 
Table 3. Table Analysis Angkur, Baseplate :

\begin{tabular}{|c|c|c|c|c|}
\hline No & Profile Data & Control & Analysis Results & Description \\
\hline \multirow[t]{6}{*}{1} & $\begin{array}{l}\text { Base Plate } \\
\text { Plate }\end{array}$ & $\begin{array}{l}\text { 1. Style Axial } \\
\text { Maximum }\end{array}$ & $750.589 \mathrm{Kg}$ & \\
\hline & Thickness: & & $720.589 \mathrm{Kg}$ & \\
\hline & $25 \mathrm{~mm}$ & 2. Lateral Style & & \\
\hline & & Minimum & $87.5 \mathrm{Kg} / \mathrm{mm} 2$ & \\
\hline & & 3. Prisoners Permint & $\begin{array}{c}\mathrm{N}<\mathrm{d} \\
91.39<400 \mathrm{~mm}\end{array}$ & Eliaible \\
\hline & & 4. Chek & $\begin{aligned} B & <b f \\
91.037 & <400 \mathrm{~mm}\end{aligned}$ & Eliaible \\
\hline \multirow[t]{5}{*}{2} & $\begin{array}{c}\text { Angkur A-307 } \\
6 \mathrm{M} 25 .\end{array}$ & 1. Check Sliding Style & $\begin{array}{c}0.366<165 \\
\mathrm{~N} / \mathrm{mm}^{\wedge} ?\end{array}$ & Eligible \\
\hline & Length of 400 & 2. Check Plate & & Eligible \\
\hline & $\mathrm{mm}$ & Resistance & $\begin{array}{c}0.288<216 \\
\mathrm{~N} / \mathrm{mm} 2\end{array}$ & Fliaible \\
\hline & & 3.Chek & & \\
\hline & & TensileStrength & $\begin{array}{c}152170.9> \\
3638.975\end{array}$ & \\
\hline
\end{tabular}

\begin{tabular}{ccc}
\multicolumn{2}{l}{ Table 4. Results table Connection Analysis } \\
\hline No & ProfileSteel & $\begin{array}{c}\text { Connection } \\
\text { s }\end{array}$ \\
\hline 1 & Pilecap & A-307 \\
& & $6 \mathrm{M} 25$ \\
2 & Columns with Beams & BoltA-325 \\
& B1 & $16 \mathrm{M} 25$ \\
3 & Columns with Beams & BoltA-325 \\
& B2 & $8 \mathrm{M} 25$ \\
5 & Beams B1 with & Bolt A-325 \\
& BeamsB2 & $4 \mathrm{M} 25$ \\
\hline
\end{tabular}

\section{CONCLUSION}

Based on data analysis and discussion on the planning of 7-story office building +1 ground floor, it can be concluded as follows:

1. Profiles used in the Preliminary design in the process of entering SAP analysis produce a value of 407 critical frames that must be changed in the steel profile.

2. 2. Changes in profile and that will be used in the planning of this office building are: Main beam / mains using profile of Steel WF $350 \times 300 \times 14 \times 23$,Child beam using Steel WF 200x 200x9x14 profile,For Columns using Profiles Steel WF 400x400x30 x50.

3. From SAP analysis then Check and control is carried out both on the main beam, beam, and Coloumn in axial, shear calculations. Moments produce structures that meet the requirements and are safe for use in office building structures.

4. In the anchor and baseplate discussion, the dimensions for anchor were obtained using M25 anchor with $400 \mathrm{~mm}$ anchor length, and25 $\mathrm{mm}$ planning for baseplate with a thickness of.

5. At the connection structure of this building using a bolt connection, with the results of an analysis using M-25 bolts with the number of bolts 16 . 


\section{Suggestions}

Suggestions that the writer can convey with the results of the analysis that has been carried out about the building of a steel frame structure are:

1. Check and control again on the calculation of buildings and placement for these structures both on columns and beams,

2. Need analysis on structural stiffness building,

3. It is necessary to analyze the calculation for pile, sloof and pilecap foundations in the planning of the office building.

\section{REFERENCES}

Budiman, Heri Khoeri. 2017. Studi Komparasi Struktur Baja Menggunakan Profil WF Terhadap Profil HSS Pada Kolom Struktur. Jakarta Pusat. Universitas Muhammadiyah Jakarta.

Fendy Phiegiarto. 2016. Perencanaan Elemen Struktur Baja Berdasarkan SNI 1729:2015. Surabaya. Universitas Kristen Petra.

Muslinang, Mustopo. 2014. Perencanaan Struktur Baja Tahan Gempa. Jakarta. HAKI.

PPIUG 1987. Perencanaan Pembebanan Indonesia untuk Gedung. Dinas Pekerjaan Umum. Setiawan, Agus. 2008. Perencanaan Struktur Baja dengan Metode LRFD. Jakarta. Erlangga.

SNI 1729:2015. Spesifikasi Untuk Bangunan Gedung Baja Struktural. Dinas Pekerjaan Umum.

SNI 1726:2012. Tata Cara Perencanaan Ketahanan Gempa Untuk Struktur Bangunan Gedung dan Non Gedung. Dinas Pekerjaan Umum.

SNI 1727:2013. Beban Minimum Untuk Perancangan Bangunan Gedung dan Struktur Lain.

Wiryanto Dewobroto. 2010. Dampak Pemakaian Design Preference Pada Rancangan Struktur. Bali. Koferensi Nasional Teknik Sipil.

https://www.google.com/maps/place/Super+Indo+Citraland/@-

7.2896652,112.6479622,540a,35y,356.02r/data=!3m1!1e3!4m5!3m4!1s0x2dd7fdc096f87 acb:0x192b51fc699a54c6!8m2!3d-7.291217!4d112.647983

http://puskim.pu.go.id/Aplikasi/desain spektra Indonesia 2011/ 